\title{
"Formation of international employee competencies in the conditions of the global labor market transformation"
}

\begin{tabular}{|c|c|}
\hline AUTHORS & $\begin{array}{l}\text { Ganna Smaliychuk } \mathbb{D} \text { https://orcid.org/0000-0001-9664-5134 } \\
\text { R http://www.researcherid.com/rid/K-6949-2018 }\end{array}$ \\
\hline ARTICLE INFO & $\begin{array}{l}\text { Ganna Smaliychuk (2020). Formation of international employee competencies in } \\
\text { the conditions of the global labor market transformation. Social and labour } \\
\text { relations: theory and practice, } 10(2), 1-9 . \text { doi:10.21511/slrtp.10(2).2020.01 }\end{array}$ \\
\hline DOI & http://dx.doi.org/10.21511/sIrtp.10(2).2020.01 \\
\hline RELEASED ON & Friday, 13 November 2020 \\
\hline RECEIVED ON & Tuesday, 02 June 2020 \\
\hline ACCEPTED ON & Wednesday, 24 June 2020 \\
\hline LICENSE & $\begin{array}{l}(c c) E Y \\
\text { This work is licensed under a Creative Commons Attribution } 4.0 \text { International } \\
\text { License }\end{array}$ \\
\hline JOURNAL & "Social and labour relations: theory and practice" \\
\hline ISSN PRINT & $2410-4752$ \\
\hline ISSN ONLINE & 2415-3389 \\
\hline PUBLISHER & LLC "Consulting Publishing Company "Business Perspectives" \\
\hline FOUNDER & $\begin{array}{l}\text { State Higher Educational Establishment "Kyiv National Economic University } \\
\text { named after Vadym Hetman", Social and Labour Relations Institute }\end{array}$ \\
\hline$\sigma^{\circ}$ & $\begin{array}{l}\text { 三ニ: } \\
\text { 三: }\end{array}$ \\
\hline NUMBER OF REFERENCES & NUMBER OF FIGURES \\
\hline 13 & 2 \\
\hline
\end{tabular}

(c) The author(s) 2021. This publication is an open access article. 


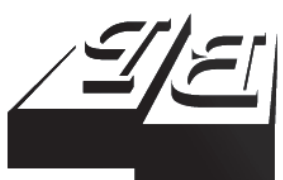

BUSINESS PERSPECTIVES

Publisher

LLC "CPC "Business Perspectives" Hryhorii Skovoroda lane, 10, Sumy, 40022, Ukraine www.businessperspectives.org

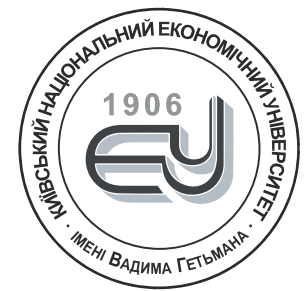

\section{HETMAN KNEU}

Founder

State Higher Educational Establishment "Kyiv National Economic University named after Vadym Hetman",

Prospect Peremogy, 54/1,

Kyiv, 03057, Ukraine

https://kneu.edu.ua/
Received on: 2nd of June, 2020 Accepted on: 24th of June, 2020 Published on: 13th of

November, 2020

\section{() Ganna Smaliychuk, 2020}

Ganna Smaliychuk, Ph.D., Senior Instructor, Kyiv National Economic University named after Vadym Hetman, Ukraine.

\section{(c) (i)}

This is an Open Access article, distributed under the terms of the Creative Commons Attribution 4.0 International license, which permits unrestricted re-use, distribution, and reproduction in any medium, provided the original work is properly cited.

\section{FORMATION OF INTERNATIONAL EMPLOYEE COMPETENCIES IN THE CONDITIONS OF THE GLOBAL LABOR MARKET TRANSFORMATION}

\begin{abstract}
Globalization of the labor market and development of international innovative cooperation, taking into account international production factors, intensify the process of forming a modern type of a migrant worker - an international worker.

Today's global market of labor resources places high requirements to the workforce. New criteria appear in relation to the quality of the individual's labor potential implemented in global economic relations, and the quality of labor, determined by the worker's qualification and skills, work attitude and sophistication of social and economic thinking, becomes the most important criterion.

The quality of labor resources in the international labor market includes many characteristics, such as availability of international work experience, knowledge of the national specifics of various countries, the importance of international communication culture, etc., which are minimally present in the characteristics of labor resources at the national level.

Given the above, the purpose of this article is to study the qualities, competencies and level of training of an innovative international worker.

The study characterized key factors of the process of developing an international worker, some of which are worth noting: the appearance of unified international requirements to the worker's education and qualification, formation of global information and communication networks, growth of transnational corporations. It was concluded that the success of a worker of an international enterprise depends on the worker's professional, social, entrepreneurial and personal competencies, etc., while the key indicators of the worker's different-culture competence profile are professional, social, entrepreneurial and personal competences, ability to learn foreign languages and current family situation.
\end{abstract}

\section{Keywords}

JEL Classification

Г. В. Смалійчук (Україна) labor market globalization, international worker, internationalization, intercultural profile

E24, F01, F22, J60

\section{ФОРМУВАННЯ КОМПЕТЕНЦЙ ІНТЕРНАЦІОНАЛЬНОГО ПРАЦІВНИКА В УМОВАХ ТРАНСФОРМАЦІЇ ГЛОБАЛЬНОГО РИНКУ ПРАЦІ}

\begin{abstract}
Анотація
Актуальний світовий ринок трудових ресурсів висуває до праці високі вимоги. Нові критерії якості трудового потенціалу особистості, яка імплементована у світогосподарські відносини визначаються не лише кваліфікацією і здібностями працівника, а й ставленням до праці, інноваційністю та рівнем розвитку його соціального і економічного мислення.

Глобалізація ринку праці, розвиток інноваційного міжнародного виробництва із залученням інтернаціональних факторів виробництва активізують процес формування сучасного типу працівника - інтернаціонального працівника.

У зв’язку з цим метою статті є дослідження питання якостей та компетенцій інноваційного інтернаціонального працівника, а також вимог до його рівня підготовки.

Автором визначено ключові фактори процесу формування інтернаціонального працівника, серед яких варто виділити такі: поява уніфікованих міжнародних вимог до освіти та кваліфікації працівника, формування глобальних інформаційно-комунікаційних мереж, розвиток діяльності ТНК тощо.
\end{abstract}


У процесі дослідження було обгрунтовано вплив вище зазначених факторів на якість трудових ресурсів міжнародного ринку праці, яка включає у себе такі характеристики як наявність міжнародного трудового досвіду, освоєння національних особливостей різних країн, значення культури міжнародного спілкування тощо, що мінімально присутні у характеристиках трудових ресурсів на національному рівні.

Методи аналізу і узагальнення наукових публікацій вітчизняних та зарубіжних авторів щодо актуальних вимог до працівників та тенденцій міжнародного ринку праці уможливили визначити, що основними складовими інтеркультурного профілю компетентності інтернаціонального працівника $€$ професійна, соціальна, підприємницька компетентність та особистісна компетентності, здібності до вивчення іноземних мов, поточна сімейна ситуація.

Ключові слова

Класифікація JEL глобалізація ринку праці, інтернаціональний працівник, інтернаціоналізація, інтеркультурний профіль

E24, F01, F22, J60

\section{ВСТУП}

Глобалізація світового економічного та інформаційного простору активізують процес прогресивних змін, в рамках якого відбувається формування нового типу працівника - інтернаціонального працівника. Сучасний глобальний ринок праці встановлює вимоги щодо якостей та характеристик сучасного працівника. Наразі глобальне переміщення працівників різного рівня кваліфікації трансформувалося у бізнес-сферу світового масштабу із розгалуженою мережею суб’єктів, що здійснюють прямий та активний вплив на процеси працевлаштування та залучення працівників. Як наслідок, дана специфічна сфера міжнародного бізнесу в рамках сучасного глобалізованого ринку праці висуває такі нові вимоги до підготовки інноваційного інтернаціонального працівника: комунікативні компетенції, високий рівень міжнародної мобільності, мультикультуралізм, знання декількох іноземних мов, готовність до крос-культурних переміщень, навички міжкультурної взаємодії, здатність до постійного професійного перепрограмування, креативність, крос-функціональність, володіння IКТ (інформаційнокомп’ютерними технологіями).

\section{1. ЛІТЕРАТУРНИЙ ОГЛЯА}

Аналіз літературних джерел показав, що проблеми трансформації міжнародного ринку праці знайшли своє відображення у дослідженнях багатьох вітчизняних та зарубіжних науковців.

Дослідженням проблем, пов'язаних з рухом людських ресурсів та з трудовою міграцією в Україні, присвячені роботи таких вітчизняних вчених як Лібанова [5], Петрова [10], у яких відзначено роль зовнішньої міграції у становленні глобального ринку праці. Значний вклад у вивчення питань інтернаціоналізації світового простору та впливу даного процесу на глобальний ринок праці здійснили Малиновська [6] та Позняк [5]. Зокрема, праці Малиновської акцентують увагу на модифікації та змінах міжнародного ринку праці, що пов’язані із адаптацією та урахуванням вимог глобального середовища. В умовах глобалізації, для нинішнього етапу якої характерне небачене зростання міжнародної мобільності працівників, міграція перетворилася на невід’ємний елемент світової господарчої системи, стала могутнім джерелом іiї розвитку. Отже, завдання полягає у тому, щоб у повній мірі скористатися вигодами міграції для модернізації, паралельно мінімізуючи обумовлені нею проблеми [6]. Крім того, Малиновська звертає увагу на процес транснаціоналізму (transnationalism) - інтенсифікацію різноспрямованої та різнохарактерної міжнародної мобільності працівників, не поділеної державними кордонами соціального простору, що формально належать до різних спільнот, організованих у формі національних держав [6].

Окремі аспекти трансформації глобального ринку праці аналізувалися такими зарубіжними вченими як Смірнова та Рязанцев, праці яких присвячені висвітленню даного питання. Зокрема, Рязанцев [11], звертає увагу на появу нових форм переміщення працівників та суттєве зростання масштабів незначних раніше трудоресурсних потоків. А саме, посилення бізнес-міграції; появи податкової міграції, коли деякі люди використовують переїзд в інші країни з метою зменшення податків; розширення інвестиційної міграції (міграція інвесторів) - переїзд осіб, які бажають вкласти гроші в створення підприємств за кордоном. 
На проблемах трансформації міжнародного ринку праці сфокусовано увагу і у звітах Міжнародної організації праці [2, 3]. Зокрема, у звіті «Глобальна зайнятість. Тенденції для молоді 2017» Міжнародної організації праці акцентується увага на перетворенні світу праці, який у майбутньому визначатиметься такими драйверами змін як демографія, зміна прагнень жінок, швидкий розвиток технологій i уніфікація культурних норми, що, у свою чергу, призведе до змін попиту на навички [3]. Традиційно глобальне виробництво структурувалося як дворівнева система: розвинені країни спеціалізувалися на капіталомістких виробничих процесах, що забезпечуються висококваліфікованою робочою силою, у той час у країнах, що розвиваються, концентрувалися на трудомістких і більш низької кваліфікації. Але технологічний прогрес призводить до змін у такому розподілі праці, що, у свою чергу, зумовлює зміни вимог до працівників на глобальному ринку праці.

3 іншого боку, у звіті «Світова зайнятість та соціальні перспективи: тенденції 2018» зазначено про необхідність врахування та комплексної оцінки структурних перетворень світових ринків праці та його вплив на форми зайнятості та умови праці [2]. Зважаючи на те, що процес структурної трансформації, як правило, характеризується поступовим перерозподілом факторів виробництва від традиційних видів діяльності (наприклад, сільського господарства та виробництва 3 низькою доданою вартістю) до сучасних, вирішального значення набуває компетентістний профіль і кваліфікаційні характеристики працівників [2]. У розвинених країнах останнім часом відбувається відхід від низькооплачуваних виробничих робочих місць до роботи, яка вимагає працівників високої кваліфікації із широким спектром різнорідних особистісних та професійних навичок. Таким чином, профіль інноваційного працівника має бути повністю інтегрованим до сучасних структурних перетворень на світовому ринку праці.

\section{2. МЕТА ДОСЛІДЖЕННЯ}

Дослідження факторів формування сучасного типу працівника - інтернаціонального працівника, визначення основних факторів, що зумовлюють інтернаціоналізацію світового простору, становлення глобального ринку праці і постійного переміщення трудових ресурсів.

\section{3. РЕЗУЛЬТАТИ}

За умов сучасної глобалізації міжнародне переміщення трудових ресурсів стає визначальним фактором, який сприяє інтеграції країн і регіонів, їх економіко-демографічному розвитку та зростанню.

Інтернаціоналізація світового простору зумовлює становлення глобального ринку праці і постійне переміщення трудових ресурсів. У цьому контексті обмеження ринку праці кордонами окремої країни мінімізується, а глобальна універсалізація економічної, соціокультурної та територіальної мереж взаємодії формує простір для подальшого розвитку міжнародних трудових відносин.

Основними характеристиками сучасного глобального ринку праці $є$ [1]:

- підвищення транснаціональної мобільності трудових ресурсів, опосередкованої засобами телекомунікацій, міжнародними потоками капіталів, товарів і послуг;

- посилення диференціації працівників на світовому ринку праці;

- $\quad$ збільшення переваг висококваліфікованих трудових ресурсів, що відповідають вимогам сучасного інноваційного прогресу, потребам нових сфер економіки;

- перетворення людського капіталу в один із ключових чинників конкурентоспроможності країн $\mathrm{i}$ компаній і в основу їх нематеріальних активів у сфері неоекономіки;

- створення нових механізмів зайнятості внаслідок трансформації глобального ринку праці;

- зміна професійно-кваліфікаційної структури працівників, поступове зникнення старих і поява нових, зумовлених інноваційним розвитком, професій, зростання зайнятості у високотехнологічних галузях і сфері послуг; 
- широке використання гнучких форм зайнятості працівників (працевлаштування на умовах контракту, тимчасове працевлаштування, робота на дому - так звані «електронні мігранти» або «віртуальні мігранти») і організації робочого часу (гнучкі режими і графіки праці, використання різниці часових поясів в закордонних філіях і представництвах компаній під час створення розкладу робочого дня);

- зростання зайнятості працівників у міжнародних компаніях або вітчизняних, що працюють на експорт.

У свою чергу, процеси змін на глобальному ринку праці посилюються під дією наступних факторів [7]:

- глобалізація;

- гнучкість ринку праці, яка вимагає посилення мобільності працівника;

- розвиток нових форм зайнятості, що вимагають універсальної освіти працівників і володіння інноваційними IКТ;

- стрімкий розвиток інформаційних технологій;

- збільшення частки інноваційної праці у світовому масштабі;

- активізація діяльності транснаціональних корпорацій (ТНК), які є одним із чинників міграції трудових ресурсів;

- трансформація трудових цінностей та формування міжнародної професійної культури у сучасних працівників;

- транснаціоналізм міграційних процесів та формування кросс-культурних цінностей у працівників.

Глобалізація ринку праці та посилення дії факторів змін зумовлюють активізацію формування інтернаціонального працівника.

Зокрема, вплив на динаміку міграційних потоків і формування інтернаціонального працівника чинить розвиток інформаційно-комунікаційних технологій у вигляді віртуальних форм організацій-інститутів працевлаштування, пошуку і підбору кадрів (інформаційно-пошукових систем, корпоративних сайтів міжнародних компаній-роботодавців, сайтів віртуальних кадрових агенцій і віртуальних служб зайнятості), розвиток IКТ, становлення транскордонної кар'єри працівників тощо (Рисунок 1).

Цей процес забезпечує широкий доступ до міжнародної інформації у сфері міжнародного працевлаштування та сприяє міжкраїнним переміщенням працівників.

Актуальним чинником глобалізації ринку праці є також розвиток сфер діяльності ТНК, які наразі, окрім ринків капіталу, технологій і товарів, інтегрують у собі також ринок трудових ресурсів. Сучасні ТНК $\epsilon$ активними стимуляторами міжнародної мобільності трудових ресурсів, адже саме вони сприяють поширенню професійних знань і активізують процес обміну досвідом між працівниками різних країн. Даний процес, у свою чергу, актуалізує розвиток глобального ринку праці, для якого характерні процеси професійної конвергенції у сфері підготовки працівників, сприяють трудовій активності населення та надають їй організованого характеру, сприяють встановленню тісних зв’язків між країнами, у яких діють ТНК та їх філії; стають чинником модернізації соціальних та економічних відносин, вдосконалення професійних компетенцій працівників ТНК та їх філій у різних країнах.

Крім того, ТНК, використовуючи працівників (у тому числі трудових мігрантів) високої кваліфікації 3 усіх країн світу, відіграють велику роль у циркулярному обміні висококваліфікованими фахівцями.

Активізація діяльності ТНК підвищує попит на працівників, що володіють високим рівнем конкурентоспроможності та відповідають міжнародним стандартам. Діяльність ТНК зумовила створення просторових моделей поділу праці і нових «товарних ланцюжків», в яких переважають нові конфігурації особистісних факторів у виробництві [13].

Актуальні тенденціїміжнародного ринкупраці формують новізапити до якостей працівників. Глобальний ринок праці та змінена система трудових відносин вимагає нового типу працівників, яким максимально 


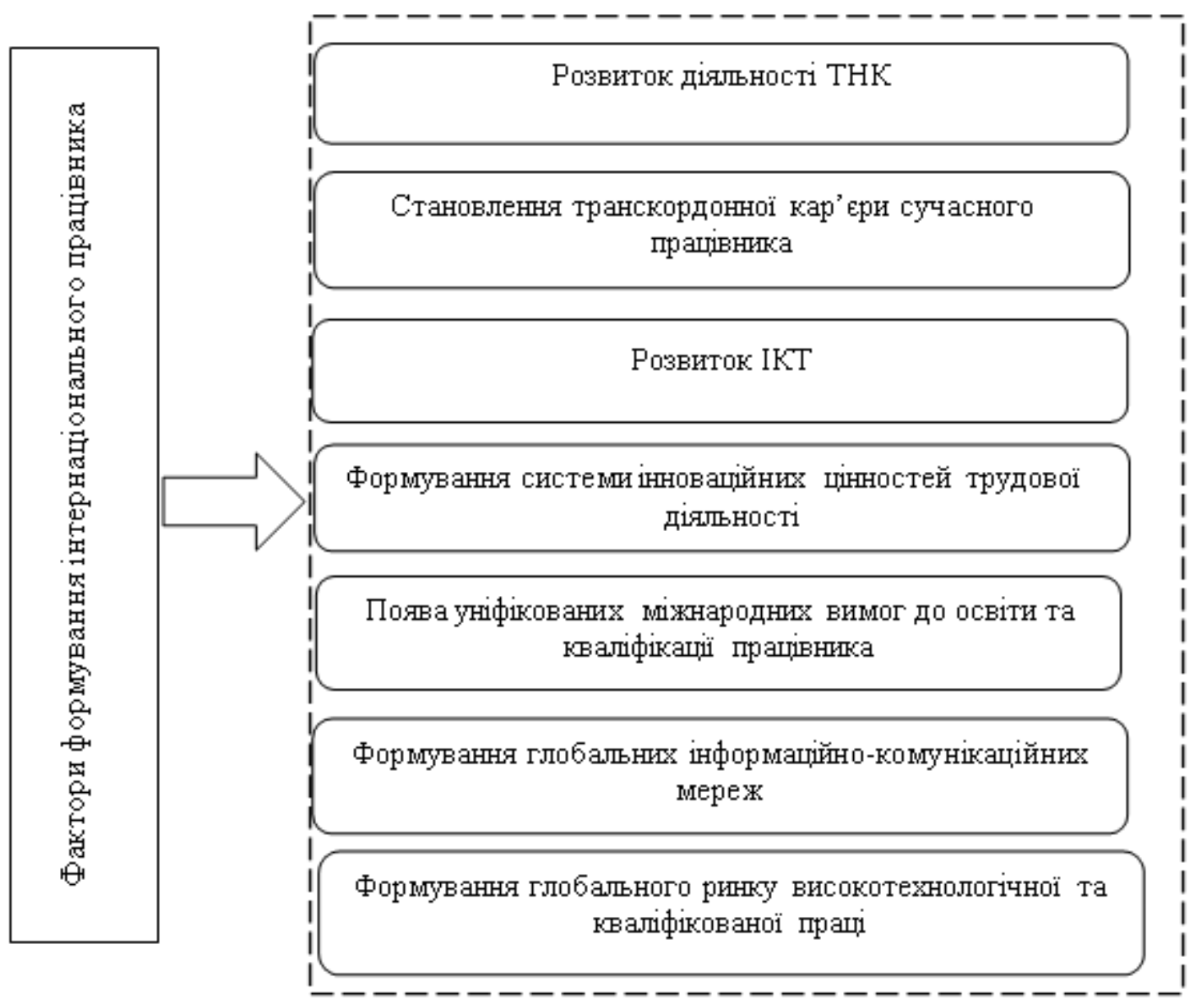

Джерело: Складено автором на основі [12].

Рисунок 1. Основні фактори процесу формування інтернаціонального працівника

притаманні характеристики міжнародних трудових ресурсів, а саме: засвоєння міжнародного досвіду і національних особливостей у різних сферах міжнародного виробництва, володіння особливостями культури міжнародного спілкування.

Наразі головними критеріями трудового потенціалу кожної окремої особистості як основного актора світових виробничих відносин є: рівень кваліфікації і здібностей працівника, якість праці, що визначається його ставленням до виконання відповідних функцій на робочому місці, розвиток інноваційного соціального і економічного мислення.

Наслідком процесу об’єднання національних ринків трудових ресурсів в єдиний міжнародний ринок праці $є$ становлення транскордонної кар'єри сучасного працівника. Зайнятість у транскордонних компаніях завдяки постійному оволодінню новими знаннями сприяє формуванню інноваційного людського капіталу. Процес кар'єрного зростання відбувається за рахунок переміщення працівників із однієї країни в іншу у рамках підрозділів транснаціональних компаній, а працівники, які є основним елементом міжнародного ринку праці, мають такі специфічні характеристики, як [9]: комунікативні компетенції, високий рівень міжнародної мобільності, мультикультуралізм, знання декількох іноземних мов, готовність до крос-культурних переміщень, навички міжкультурної взаємодії, здатність до постійного професійного перепрограмування, креативність, крос-функціональність, володіння ІКТ [12]. Крім того, необхідними є наступні професійно значущі якості: адаптивність, гнучкість, толерантність, розвинені крос-культурні цінності. 
Основними категоріями інтернаціональних працівників є: працівники, які виїхали за кордон та $\epsilon$ самозайнятими, персонал ТНК, працівники міжнародних організацій, працівники мігранти, які працюють за міжнародними контрактами за кордоном, працівники вітчизняних компаній, які працюють за індивідуальними контрактами у закордонних компаніях.

Оскільки сучасні працівники-мігранти встановлюють, підтримують та розвивають всі види відносин (сімейні, соціальні, економічні, політичні, організаційні та релігійні відносини) крізь кордони, то працівники на сучасному етапі перетворюються на трансмігрантів та інтернаціональних працівників, ознакою яких $є$ те, що їхні інтереси (економічні, політичні, особистісні тощо) знаходяться як в країніреципієнті, так і на батьківщині.

Формування та функціонування інтернаціонального працівника спричинило також формування інтернаціональної ціни трудових ресурсів, виникнення уніфікованих вимог до рівня освіти та кваліфікації працівників, типових трудових контрактів та стандартизації умов праці, що, у свою чергу, впливає на заробітну плату на світовому та національному ринках праці.

Ефективність працівника інтернаціональних підприємств залежить від наявності у нього професійної, соціальної, підприємницької та особистісної компетентностей, здібностей до вивчення іноземних мов, а також від сімейної ситуації.

Показники інтеркультурного профілю компетентності працівника (Таблиця 1) не можливо розглядати як статичні. Еволюція діяльності підприємства у міжнародному форматі передбачає, що планувати дії за кордоном потрібно з урахуванням змін, що відбуваються в країні, її ринкових умов.

Таблиця 1. Показники інтеркультурного профілю компетентності працівника

\begin{tabular}{|c|c|}
\hline Показник & Характеристика показника \\
\hline Профресійна компетентність & $\begin{array}{l}\text { - технічні знання; } \\
\text { - знання діяльності підприємства у країні-реципієнті; } \\
\text { - здібності менеджера; } \\
\text { - адміністративна компетентність. }\end{array}$ \\
\hline Соціальна компетентність & $\begin{array}{l}\text { - толерантність щодо ситуацій невизначеностей; } \\
\text { - гнучкість у поведінці; } \\
\text { - вміння вирішувати конфлікти; } \\
\text { - свобода від упереджень; } \\
\text { - здатність працювати у команді; } \\
\text { - культурна емпатія та низький рівень етноцентризму; } \\
\text { - здібності у налагодженні відносин та міжособистісного спілкування. }\end{array}$ \\
\hline $\begin{array}{l}\text { Підприємницька } \\
\text { компетентність }\end{array}$ & $\begin{array}{l}\text { - здібність до підприємницького мислення; } \\
\text { - здатність до налагодження підприємницьких контактів, вміння ідентифікувати себе з цілями } \\
\text { підприємства та брати на себе відповідальність за реалізацію організаційних інтересів; } \\
\text { - усвідомлене відношення до витрат, ризиків та доходів; } \\
\text { - віра у місію. }\end{array}$ \\
\hline Особистісна компетентність & $\begin{array}{l}\text { - бажання отримати закордонний досвід; } \\
\text { - інтерес до специфічної культури країни-реципієнта; } \\
\text { - готовність до сприйняття нового способу життя, нових установок та поведінки; } \\
\text { - гнучкість; } \\
\text { - виносливість; } \\
\text { - володіння методами зменшення стресу, зумовленого перебуванням в умовах іншої культури. }\end{array}$ \\
\hline Поточна сімейна ситуація & $\begin{array}{l}\text { - готовність сім'ї жити за кордоном; } \\
\text { - наявність дружини/чоловіка, здатних пристосуватися до життя в іншій країні та виявляти } \\
\text { підтримку. }\end{array}$ \\
\hline $\begin{array}{l}\text { Здібності до вивчення } \\
\text { іноземних мов }\end{array}$ & $\begin{array}{l}\text { - знання мови країни-реципієнта; } \\
\text { - здібність до невербальних комунікацій. }\end{array}$ \\
\hline
\end{tabular}


На світовому ринку трудових ресурсів до працівників висуваються досить високі вимоги. Виникає новий сенс трудового потенціалу суспільства - не лише як сукупності населення у межах певної країни, а і як загальної чисельності трудових ресурсів світового ринку праці. Міжнародний ринок формує особливий тип універсалізованих гнучких трудових ресурсів як носія національних культур і традицій, сферою докладання праці яких стає світове господарство загалом [9].

Причини та необхідність зосередження на розвитку компетенцій інтернаціонального працівника у 21-му столітті, є багатогранними і пов'язані з наступними факторами [8]:

- змінами у використанні трудових ресурсів від промислової моделі виробництва до такої, що швидко трансформується, технологічної та взаємопов’язаної із глобалізованою економікою знань, яка вимагає компетентності, що відповідає динамічним і непередбачуваним моделям економічного і соціального розвитку;

- появою необхідності оптимізації навчання, включаючи використання технологічних інновацій для поглиблення та трансформації навчання;

- змінами очікувань з боку споживачів освітніх послуг, які вимагають системи освіти, що є більш пов’язаною із сучасними вимогами та актуальною для їхнього кар'єрного зростання.

Компетенції працівників на міжнародному ринку праці у 21 сторіччі пов’язані із зростанням частки тих сфер зайнятості, що вимагають розвитку когнітивних, міжособистісних і внутрішньоособистісних сфер (Таблиця 2).

Таблиця 2. Прогнозовані зміни щодо частки зайнятих за сферами працевлаштування в $\mathrm{EC}$, 2016-2030 рр. (для держав-членів ЄC-28)

Джерело: Складено авторами на основі [2]

\begin{tabular}{|c|c|c|c|c|}
\hline Частка зайнятих, \% & 2016 & 2021 & 2026 & 2030 \\
\hline Законодавці, вищі посадові особи та менеджери & 6.4 & 6.5 & 6.7 & 6.8 \\
\hline Професіонали & 17.8 & 18.1 & 18.4 & 18.7 \\
\hline Техніки та професіонали & 16.4 & 16.9 & 17.3 & 17.8 \\
\hline Клерки & 10.3 & 10.0 & 9.7 & 9.4 \\
\hline Працівники сфери обслуговування і працівники сфери продажів & 17.1 & 17.1 & 17.0 & 16.8 \\
\hline Робітники сфери сільського господарства & 3.8 & 3.5 & 3.4 & 3.2 \\
\hline Ремісничі професії & 11.4 & 10.9 & 10.5 & 10.2 \\
\hline Оператори машин і складальники & 7.0 & 6.9 & 6.8 & 6.8 \\
\hline Елементарні професії & 9.8 & 10.0 & 10.2 & 10.4 \\
\hline Усі профресії & 100.0 & 100.0 & 100.0 & 100.0 \\
\hline
\end{tabular}

Ключовими показниками успіху та одночасно вимогами з боку роботодавців $є$ когнітивні компетенції у критичному мисленні, аналізі та вирішенні проблем [4]. Крім того, зміни у економічних, технологічних та соціальних сферах спричиняють важливість міжособистісних та внутрішньоособистісних компетенцій. Роботодавці все частіше цінують такі особистісні компетенції, як робота в команді, лідерські та соціальні навички [8], які стають фактором, що визначає професію і заробітну плату та впливають на перспективи працевлаштування на міжнародному ринку праці.

Крім того, дослідження у галузі охорони здоров’я та благополуччя виявили, що такі характеристики, як наполегливість, сила волі і сталість щодо досягнення мети, іноді є більш точним предиктором успіху, ніж рівень інтелектуального розвитку. Наприклад, серед внутрішньоособистісних компетенцій характеристика сумлінності (тенденція до організованості, відповідальності та працьовитості) максимально корелює з бажаними результатами освіти, кар’єри та здоров’я [8].

3 іншого боку, Конференція Ради Канади у 2000 р. [8] визначила, що необхідними у сфері міжнародної зайнятості $є$ розвиток навичок у трьох аспектах: фундаментальні навички (спілкування, управління інформацією, використання чисел, мислення та вирішення проблем); навички персонального управління 
(вміння демонструвати позитивне ставлення та поведінку, відповідальність, адаптивність, здатність до безперервного навчання); навички роботи в команді (участь у спільних проектах та завданнях). Вона також профілізує інноваційні навички у таких напрямках як навички творчості, вирішення проблем та постійного самовдосконалення; оцінювання ризиків та неухилення від них.

\section{ВИСНОВКИ}

Глобалізація ринку праці, розвиток інноваційного міжнародного виробництва із залученням інтернаціональних факторів виробництва активізують процес формування нового типу працівника інтернаціонального працівника. Як наслідок, за сприяння міжнародних посередників ринків праці відбувається включення таких працівників у міжнародні процеси виробництва та праці.

Інтернаціональний працівник перетворюється в активного учасника інноваційних виробництв та необхідним фактором сучасного процесу міжнародних трудових відносин, а його основними та важливими характеристиками стають комунікативні компетенції, високий рівень міжнародної мобільності, мультикультуралізм, знання декількох іноземних мов, готовність до крос-культурних переміщень, навички міжкультурноївзаємодії, здатність до постійного професійного перепрограмування, креативність, крос-функціональність, володіння IКТ, адаптивність, гнучкість, толерантність, розвинені крос-культурні цінності.

Якість трудових ресурсів на міжнародному ринку праці визначається наявністю міжнародного трудового досвіду, знанням національних особливостей та культури міжнародного спілкування тощо - характеристиками, що у меншій мірі притаманні працівникам на національному рівні, але перетворюються на необхідні для інтернаціональних працівників.

\section{НАПРЯМИ ПОДАЛЬШИХ ДОСЛІДЖЕНЬ}

у сучасних умовах актуалізується дослідження окремих складових інтеркультурного профілю компетентності працівника на міжнародному ринку праці. Набуває важливості вивчення досвіду підвищення якості та конкурентоспроможності трудових ресурсів поза межами національних ринків праці, що, у свою чергу, вимагає необхідності зосередження досліджень у сфері розвитку компетенцій інтернаціонального працівника, сферою докладання праці яких стає світове господарство у цілому.

Наразі міжнародний ринок праці вимагає подальшого вивчення того типу універсальних трудових ресурсів, які сформувалися на даному етапі та є носієм національних культур і традицій усіх країн світу.

\section{AUTHOR CONTRIBUTIONS}

Conceptualization: Ganna Smaliychuk.

Data curation: Ganna Smaliychuk.

Formal analysis: Ganna Smaliychuk.

\section{СПИСОК ЛІТЕРАТУРИ}

1. Electronic library of international relations (n.d.). Svitoviy rinok pratsi yogo struktura ta osoblivosti formuvannya [The world labor market is its structure and peculiarities of formation]. (In Ukrainian). Retrieved from http://kimo.univ.kiev.ua/MEO/25.htm

2. European Training Foundation (2019). The future of work and skills in ETF partner countries. Retrieved from https://www.etf.europa.eu/sites/default/ files/2019-07/Future\%20of\%20work\%20and\%20skills_Issues\%20paper.pdf

3. International Labour Office (2017). Global Employment Trends for Youth 2017: Paths to a better working future. Retrieved from https://www.ilo.org/wcmsp5/groups/public/---dgreports/---dcomm/---publ/documents/publication/wcms_598669.pdf

4. International Labour Office (2018). World Employment and Social Outlook: Trends 2018. Retrieved from https://www.ilo.org/wcmsp5/groups/public/--dgreports/---dcomm/---publ/documents/publication/wcms_615594.pdf

5. Libanova, E. (Ed.) (2008). Liudskyi rozvytok v Ukraini: innovatsiinyi vymir [Human development in Ukraine: the innovation dimension] (316 p.). K: IDSD NANU. (In Ukrainian) 
6. Malinovska, O. (2009). The International Migrations and the Social Transformation of the Globalization Epoch. Demography and Social Economy, 1, 5-19. (In Ukrainian). https://doi.org/10.15407/dse2009.01.005

7. Mazaraki, A., \& Shklyaruk, K. (2015). Doslidnytskyi universytet yak uchasnyk systemyrozvytku vyshchoi osvity v Ukraini [Research University as a participant in the system of higher education development in Ukraine]. In A. Mazaraki (Ed.), Problemi ta perspektivi rozvitku innovatsiynoyi diyalnosti v ukrayini: VIII mizhnarodniy biznes-forum [Problems and Prospects for the Development of Innovation in Ukraine: The VIII International Business Forum] (pp. 157-158). (In Ukrainian). Retrieved from https://knute.edu.ua/file/MTc=/1e8a62d3ca6647b78fd23992ec0eb32d.pdf

8. Ontario (2015). 21st century competencies. Retrieved from http://www.edugains.ca/resources21CL/About21stCentury/21CL_21stCenturyCompetencies.pdf

9. Patlasov, O. (2016). International labor migration and internationally focused human resources targeted marketing. The Science of Person: Humanitarian Researches, 25, 188-194. (In Russian). Retrieved from http://journal.omga.su/files/25/188-194.pdf

10. Petrova, T. (1996). Kontseptsiia derzhavnoi mihratsiinoi polityky: tsilova oriientatsiia i osnovni napriamky [The concept of state migration policy: target orientation and main directions] (41 p.). K: NTSZRP. (In Ukrainian)

11. Ryazantsev, S. (2001). Vliyaniye migratsii na sotsialno-ekonomicheskoye razvitiye Yevropy: sovremennyye tendentsii [The impact of migration on the socioeconomic development of Europe: current trends] (542 p.). Stavropol: Stavropolskoye knizhnoye izdatelstvo. (In Russian)

12. Smaliychuk, G. (2018). Zovnishnia trudova mihratsiia naselennia Ukrainy ta yii vplyv na transformatsiiu rynku pratsi [External labor migration of the population of Ukraine and its impact on the transformation of the labor market] (Ph.D. Thesis) (289 p.). Kyiv: KNEU. (In Ukrainian)

13. Smirnova, D. (2015). The Influence of the Integration Process on the Development of Contemporary Labor Market. Bulletin of the Volga Region Institute of Administration, 2(47), 121-126. (In Russian). Retrieved from https://papers.ssrn.com/sol3/papers.cfm?abstract_id=2619645 